\title{
Top-down and out?
}

\section{Reassessing the labelling approach in the light of corporate deviance}

\author{
Anna Merz
}

\section{Introduction}

The neo-liberal agenda is often associated with a lack or unwillingness of formal responses to corporate deviance (Friedrichs, 2007; 2009; Garret, 2014; Levi, 2009; Van Stokkom, 2018). Parallel to the further development of neo-liberalism and the withdrawal of the state, movements of social disapproval have developed in which other parties take over the state's regulatory role. Neo-liberal markets are thus also characterized by a considerable amount of regulation and control by private regulators (Van Erp, 2016). As a result, institutions and corporations are shamed and held liable by different kinds of actors. In recent times, both public attention and the number of cases brought against (multi-national) corporations appears to be increasing (Elffers, Van Bemmelen, Hesseling, Ramaker, 2019; Van Erp, 2016). Charges range from human rights violations and environmental concerns to tax evasion and money-laundering practices. The multitude of cases against the British-Dutch oil and gas company Royal Shell (hereafter Shell) illustrates this increase and the duality of state and other party control. Shell is facing several ongoing or recently settled cases in different countries and jurisdictions and by different parties. Firstly, we see formal responses by official authorities. For their involvement in a 1.1 billion dollar corporate corruption scandal on securing a deal on the Nigerian oil-rich OPL-245 offshore field, Shell is currently in court in Italy and the Netherlands. In Italy, four ex-Shell managers are facing charges of international corruption; in the Netherlands the case is largely hampered by Shell advocates (Rengers \& Houtekamer, 2019). In another case, an investigation by the Netherlands Public Prosecution Service (NPPS) into the gas explosion and leakage of chemical emissions at Shell's Moerdijk facility (one of the corporation's largest chemical complexes in Europe, located in the Netherlands) has recently resulted in a fine of 2.5 million euros (NPPS, 2019). Shell was accused of breaching environmental and safety regulations and thus accepting "the considerable chance that things would go wrong" (NPPS, 2019). Secondly, we see responses by third parties. Several environmental organizations and 17,379 co-plaintiffs have started a climate lawsuit against Shell as the "biggest polluter of the Netherlands" (Milieudefensie, 2019). A different case concerns the cooperation between the Rotterdam School of Management (RSM), one of the largest faculties of the Erasmus University Rotterdam, and Shell. RSM has, in December 2018, terminated its long-lasting cooperation contract with Shell; the cooperation came under scrutiny in 2017 after the publication of a report by sustainability think tank Changerism. The report was followed by growing media attention, local 
and national outrage, parliamentary debates and the online appeal \#KillTheContract geared towards RSM to end the cooperation (Hüzeir, 2019). Remarkably, the contract was terminated rather silently with the absence of a clear statement by RSM. The faculty's action can thus be interpreted as a last resort to protect its own reputation and interests, trying to limit any further negative responses by third parties. And lastly, we see reactions by Shell. The corporation continuously claims to embrace the Paris Climate Agreement and emphasises this by launching various green projects and campaigns and accusing others of taking insufficient measures. Shell is the first major oil company to cancel its membership of the influential American lobby club American Fuel \& Petrochemical Manufacturers (AFPM), an organization to which more than three hundred oil companies are affiliated (Bousso, 2019). According to Shell, the climate ambitions of the lobby organization do not go far enough. It is worth mentioning that making the company more sustainable is financially beneficial for Shell's top managers; executive annual bonuses are tied to sustainable development (energy transition condition) and executive remuneration will be more closely linked to carbon goals in the future (Shell, 2018).

The above mentioned reactions illustrate that disapproval of corporate harms by different parties is on the rise. This article will examine such reactions from a social-constructionist perspective. Using Becker's (1963) approach of labelling, it focuses on responses to corporate norm-violations in the digitalized, late-modern society. This article thus aims to contribute to the scant literature on labelling corporations (see Benson, 1984; Brants \& Brants, 1991, Huisman, 2011). It strongly contests other scholars' beliefs that corporations are not and/or cannot be labelled (see e.g. Moerings, 2017; Schur, 1971; Vaughan, 2007). These claims are usually rooted in the traditional labelling approach. In the traditional labelling approach, the process of successfully labelling somebody requires social or political power (Schur, 1980). Labelling is then mainly executed top-down on people in lower positions of power. The context of digital globalization and the rise of social media is unique for the labelling approach as it gives all kinds of people a platform to express their concerns on corporate harms. This, however, poses a dilemma for the traditional process of labelling. This article will therefore discuss how the process of labelling has changed and should be revisited to be applicable for corporate deviances. The analysis presented in this paper is based on a theoretical examination of existing literature and case studies of 'corporate scandals'.

While corporate deviance has, so far, largely been neglected by labelling theorists, this article proposes that a combination of the concepts can offer interesting insights into the phenomenon of corporate deviance and raises important questions for criminologists regarding the question of what is deviant in the corporate context. I will speak of corporate deviance instead of corporate crime, to highlight the selectivity and subjectivity of the definition and construction of deviant behaviour. Moreover, this stresses a harm-based understanding of corporate norm-violations, including practices which are "awful but lawful" (Passas, 2005). 
1. Primary deviancy: Violation of a norm

2. Societal reaction to primary deviancy, dependent on

a. Characteristics of actor

b. Characteristics of act

c. Characteristics of victim

d. Characteristics of the audience

e. Characteristics of the situation

3. If characterized as problematic: exclusive reaction, assignment of 'criminal' label, stigmatisation and othering

4. Label becomes master status which overrules other statuses

5. Adaptation and internalization of label by the offender resulting in a change in selfidentity

Figure 1 Traditional process of labelling (see Becker, 1963; Lemert, 1972;

Schur, 1971)

\section{The traditional labelling approach}

To construct the revisited labelling approach, the article will firstly outline the traditional approach and its varieties. These will form the point of departure for the reassessment. The labelling approach finds its roots in the work on symbolic interactionism by Mead (1934) and Blumer (1969). According to symbolic interactionism, the self is developed through communication with others (Blumer, 1969; Mead, 1934). Meaning is assigned to behaviour by human interaction through symbols and the interpretation of these (Blumer, 1969). This dynamic process of giving, identifying and interpreting meaning is constantly changing and adapting in society. Deviance is then created in social interaction by society's reaction to it (Becker, 1963). The interplay between the self and society has a central role in the labelling approach. Following up on symbolic interactionism, the labelling approach regards deviancy as a social construction which is shaped by the rule making of (powerful) individuals and their responses to rule-breakers (Mead, 1918; Becker, 1963; Lemert, 1972). In Becker's (1963: 9) words: “Social groups create deviancy by making the rules whose infraction constitutes deviance, and by applying those rules to particular people and labelling them as outsiders."

\section{The labelling process}

Drawing on the works of Becker (1963), Lemert (1972) and Schur (1971), the (traditional) labelling process can be summarized in five steps (see Figure 1).

The initial act of rule-breaking, also known as primary deviancy (step 1) is a common phenomenon in society (Lemert, 1972). This initial form does not cause any long-term consequences for the offender per se if it is either not followed by any societal reaction at all or at least not by a stigmatising one. Whether an act or violation of rule is regarded as deviant, thus whether step 3 and 4 will occur, is merely dependent on the characteristics of the act, actor, victim, audience and situation (step 2 a-e). The same act can thus invoke different reactions and in one 
situation be labelled as deviant while being regarded as unproblematic in another situation. The act of labelling is thus by all means intersubjective and selective. Reactions do not match the initial, objective harm done (Becker, 1963).

While at first the deviant label only condemns the act, a further involvement of stigma eventually leads to a "dramatization of evil" in which the offender is viewed as evil (Tannenbaum, 1938). The public identification of the 'criminal' results in the segregation, othering and labelling of people as outsiders (Becker, 1963; Tannenbaum, 1938). In this phase, the deviant tag or label becomes a master status (step 4) overruling all other status the labelled individual possesses (Becker, 1963). Lastly, the labelling process can eventually result in the adaptation of an imposed label by the individual, taking on the deviant-image and behaving in accordance with it (step 5).

\section{Varieties of labelling}

The labelling approach has inspired and triggered the emergence of several related theories and concepts (see e.g. Braithwaite, 1989; Cohen, 1972; Garfinkel, 1956; Van Erp, 2007). These varieties of labelling have shifted the focus of the approach in different directions and open the path for a 'new' labelling approach. They thus serve as an indicator for the adaptability of the labelling approach, but also provide an overview of existing adjustments to the traditional labelling approach. Adapting however entails challenges. Other approaches have explicitly been criticized for losing their focus by 'opening up'. 'New' moral panics, to give one example, which go beyond the initial focus on societal moral crisis and deviant behaviour of adolescents by incorporating for instance political scandals, climate change or violent movies and confusing it with any type of media hype have led to a dilution of the concept (Bouabid, 2018). Likewise, it is argued that the emergence of varieties of labelling has contributed to the common practice of using the term as a container concept for different kinds of processes. Imprecision on the distinction between these has led to much confusion, misinterpretation and wrongful criticism of the approach. An inflationary use of 'labelling' can thus weaken the concept. That increases the need for a clarification of what labelling actually entails.

Most research on the labelling approach, and thus most scholars' understanding of labelling, focuses on formal labelling by official authorities (Matsueda, 1992; Schur, 1971). Processes of informal labelling by (significant) others, in contrast, are often neglected in research or solely researched in the context of adolescent deviancy (Matsueda, 1992). In Becker's Outsiders, on which this analysis is mainly based, labelling is, however, not limited to official authorities. Rather, he also includes the labelling of (and between) dance musicians and marijuana users and the significance of these for the self (Becker, 1963). The labelling approach is thus often wrongfully attributed with a narrow understanding that is limited to formal labelling (Schur, 1971). It then neglects that labelling can emerge from a more diverse group of social actors (informal labelling). The latter will be discussed in more detail in this article. For the focus on corporate deviance, the practice of 
shaming is relevant too. Firstly, labelling might be confused with shaming (Braithwaite, 1989) and secondly, in contrast to the labelling perspective, (naming and) shaming has been extensively researched within the context of corporate and white-collar crime (see e.g. Braithwaite, 1989; Van Erp, 2007) and gained popularity in the light of more repressive and punitive developments. Shaming can be understood as the social process of (publicly) expressing disapproval and drawing attention to certain actions as means of punishment (Braithwaite, 1989). Naming and shaming then refers to the public exposure of offenders (naming) and colouring of the exposed information in a negative way (shaming). Responses can vary between more neutral naming practices for the purpose of transparency and shaming that is explicitly stigmatising (Van Erp, 2007). Examples include the non-governmental organization Greenpeace naming and shaming, inter alia, Nike and Adidas for the dumping of toxic chemicals in rivers in Asia (2011) or the naming and shaming of several garment corporations, including Primark, Walmart and Mango, after the collapse of the Rana Plaza factory in Bangladesh (2013). The fourth Anti-Money Laundering Directive by the European Union requires authorities to disclose a minimum standard of information on administrative sanctions such as the type and nature of violations and the identity of the persons responsible; financial regulatory authorities such as the Netherlands Authority for the Financial Markets are obliged to disclose sanctions on their homepage. In line with the labelling approach, shaming focuses on societal reactions to behaviour. Unlike labelling, shaming does not focus on reactions to construct deviancy and thus is not concerned with the historical, political, cultural and social processes that lead to (the absence) of behaviour being deemed deviant. Labelling is thus broader than shaming. Shaming can be part of the labelling process, but not necessarily. The study by Van der Wagen, Althoff \& Van Swaaningen (2016) on hackers exemplifies this broader focus, incorporating three dimensions of labelling: how do hackers think they are perceived by the outside world?; how do they see themselves?; and how do they as 'outsiders' see themselves in relation to their own (hackers) community and beyond? The interaction between the first two dimensions is important for the labelling perspective as someone's self-concept is influenced by how he/she perceives or imagines others to see (and classify) him/her (Goffman, 1963). Moreover, shaming substantially differs from the labelling approach with regards to the importance of the acceptance of the social norms. Labelling is explicitly rooted in the divergence of norms and is therefore exclusive in nature; shaming on the contrary may be inclusive.

Besides the initial process of labelling (see Figure 1), labelling is often conflated with a second meaning or process, namely secondary deviancy (Lemert, 1972). Many early critics of the labelling approach focus on the element of secondary deviance, claiming that this reinforcement of deviancy lacks empirical evidence and clarity. Recent studies (see e.g. Bouabid, 2018; Van der Wagen et al., 2016) have found no evidence for this second process of labelling either. Although Becker (1963) referred to the manifestation of criminal careers as a result of the process of labelling, he later insisted that secondary deviancy should not be the focus of the labelling approach (Becker, 1973). The approach should rather focus 
on the interactionist process of how and by whom deviancy is defined and the dynamic relation between (deviant) behaviour, the reaction it evokes and the counter-reaction that follows. Therefore, this paper takes the labelling approach back to its roots of symbolic interactionism and the initial work by Becker. Against the practice of using labelling as a container concept, it argues for a reinvention of the labelling approach in its original sense, where the act of labelling describes the social reaction to and thereby construction of deviance (Becker, 1963).

\section{Setting the context: The transformation into late modernity}

This section will briefly outline how society and especially communication and meaning-generating has transformed in recent times and elaborate on the concept of 'late modernity' as a framework to capture this transformation. The rise of information technology sets a unique context in which labelling nowadays should be understood. Late or liquid modernity as Bauman (2012) refers to it, captures our contemporary society as fragmented, but also increasingly global communities with fluid people and identities (Bauman, 2012) and an increasingly virtual linkage and interactive communication via social media (Aas, 2013; Friedrichs, 2007). Or, as Van Erp (2016: 9) notes, an 'open society' characterized by its boundlessness, connectivity and dense and rapid exchange. Most aspects of people's (everyday) lives are linked to social media nowadays (Aas, 2013), making it a ubiquitous part of society. It will be argued that social media, as a low-cost, highly interactive, fast and multidirectional means of communication (Aas, 2013; Whelan, Moon \& Grant, 2013), opens doors for people to label powerful actors, reaching large amounts of people. By offering people a platform and access, the Internet breaks with the monopoly of information held by 'old media'. Three functions are important to understand the role of the Internet, and especially social media, for the process of labelling; that is empowerment, connectivity and control.

Empowerment: As a cheap, fast and easy means of communication, the Internet lowers the barriers for interactions (Aas, 2013; Whelan et al., 2013). Social media often serve as a platform of exposure; exposure of personal and private aspects of the lives of common people, politicians or corporations. Secrets are publicly shared, with or without the consent of those involved (Aas, 2013). As literally everything can be exposed, the boundaries between private and public become increasingly blurry. This is possible as the Internet enables people to enter the public sphere and express concerns directly, without the help of an intermediary stance such as publication houses or reporters for newspaper contributions. Through social media, the powerless (just like the powerful) can express their views, voice their grievances and mobilize to stand up against the powerful. In that respect the Internet and social media are spaces of flat hierarchies. Social media thus relatively (read: relative to the power of corporations) empower people to engage in processes of labelling themselves (Whelan et al., 2013). 'Old media' (TV, radio, newspaper) used to be in the hands of a few media organizations and 
were mainly guided by elite voices, thus following a rather one-sided picture (Yar, 2012). Contemporary (digital) mass media and means of communication are characterized by a sheer overload of available information and facilitated access to these by a diverse group of people (Aas, 2013; Castells, 2015). The expansion in participation of actors has transformed this "few-to-many" interaction into a "many-to-many" exchange (Yar, 2012). Likewise, the "one-way structure" (Yar, 2012) with a clear direction of the information flow has changed into a multidirectional structure in which users become producers themselves (Whelan et al., 2013). People and organizations can create and respond to labels in this multidirectional network.

Connectivity: The late-modern society is increasingly connected and disconnected at the same time. On the one hand, one electronic signal is enough to communicate and interact with people around the globe (Davis, 2008). Local happenings are increasingly shaped by global events and vice versa. This entails that news, cultural images and ideas travel and experiences are shared in a global context (Aas, 2013; Davis, 2008). Information technology thus enables people to connect. The Internet gives room for a more active interaction through either public platforms (many-to-many) such as Facebook, Twitter, LinkedIn, Instagram or YouTube or closed, more inclusive (one-to-one) networks such as WhatsApp, WeChat, Skype or Telegram. These interactions are relatively unfiltered, especially in closed one-to-one networks. That means that, within the given framework of social media platform, basically anything can be shared online. Likewise, social disapproval, and possible labelling, can easily be shared with many people. Before, sharing our beliefs and opinions was restricted to a limited, offline network. Nowadays, they can be made (publicly) available with only one click, possibly reaching millions of people. Labelling in the online sphere can thus emerge very rapidly. At the same time, there is a growing disconnectedness as social media promote self-communication as the sharing and consumption of news are selfselected (Castells, 2015). It thus follows one of the core ideas of the Frankfurt School; that is "the freedom to choose what is always the same". The complex and diverse contemporary (social) media landscape is fragmented and polarizing as it provides an infrastructure to connect with like-minded people and operate in an online-bubble (Bauman, 2012; Castells, 2015). Deviant behaviour can then more easily reach a problematic status in certain communities of like-minded users that share similar views of what is, for instance, right or wrong, good or bad or moral or amoral and as a result might more easily get labelled as such.

Control: The developments mentioned so far, however, only mark one side of the coin. The Internet and social media networks are not anarchic spaces. Rather, the integration of our lives in the digital world also creates a dependency and comes at a price, as the resources of information technology are concentrated in the hands of a few powerful players; that is the big tech companies, namely Google, Facebook, Apple, Amazon and Microsoft (also known as the Big Five). A news article recently published by the Dutch Newspaper NRC equates the Big Five's turnover, amounting to about 715 billion euros last year, with the national 
income of the Netherlands (Beunderman, 2019). By using their services, people are constantly feeding them with information. As a result, these corporations command an enormous amount of data and information on every one of us which is used to influence people's decisions by, for instance, targeted advertising. So, while the Internet does offer opportunities and facilities for communication and interaction, it also serves as a new means of (social) control. In that sense, social media corporations are actively shaping (or controlling) people's responses. They are constantly adapting possibilities to capture users' reactions. Using artificial intelligence, the social networking service Instagram has recently introduced control features such as asking people who are about to post offensive information whether they are sure that they want to post this. What can be seen as a (positive) response to a growing social concern of incidents of online bullying, can on the other hand also be framed as another means of further controlling and restricting users. Means of communication and thus reactions are free only in so far as they fit the given framework that the powerful, thus social media corporations or governments, set.

Within these three functions of empowerment, connectivity and control, online social platforms have not only virtually empowered people to speak up, they have also created room for the distribution of, for instance, hate speech, fake news or the creation of "the other" (Aas, 2013). The distance and alienation that comes with the digital space also lowers the threshold for more extreme and stigmatising positions and verbal attacks. Alongside the facilitation of expressing one's opinion, the Internet creates a protective shield against real (social) consequences and informal social control by offering anonymity and intangibility (Aas, 2013). As people's lives are increasingly influenced and controlled by information technology (and its corporations), any approach to labelling should incorporate the transformation into late-modernity and consequently, the third space of the Internet. Comparably, digital globalization and especially the rise of social media has changed the mechanisms and impact of naming and shaming practices (Nelen \& Van Gemert, 2018; Van Erp, 2016). While the disclosure of sanctions by (regulatory) authorities "after thorough investigation" used to be characteristic for naming and shaming, it has, for a large part, now transformed into trial by media and public practices of corporations being pilloried on (social) media, regardless of whether accusations are founded and before investigation are completed, thoroughly examined or even started (Nelen \& Van Gemert, 2018). That has led to an opening up towards broad societal movements as principal actors and instant but serious naming and shaming in the online sphere. In line with that, the following will discuss how the process of creating 'the other' has changed with the rise of social media, and apply the labelling perspective to the context of corporate deviance. 


\section{Towards a revisited labelling approach for corporate deviance}

In line with Becker's (1963) concept of labelling, for corporate deviances we almost always see a mismatch of the objective harm and the subjective reactions. In contrast to street crimes, however, this mismatch usually benefits the offender (read: corporations). In other words: the labelling of corporations is often hampered (Brants \& Brants, 1991; Box, 1983; Moerings \& Van de Bunt, 1976). While many corporate deviances have been criminalized, they often come with a lack of formal enforcement (Garret, 2014), symbolic presence of laws (Braithwaite, 1989) and bifurcation as the social definition of economic crimes still greatly varies from the moral definition of common crime (Brants \& Brants, 1991). Other corporate deviances are "awful but lawful" (Passas, 2005) as they cause harm within the given legal framework. Practice shows that corporations continuously manage to escape (the stigmatising consequences of) labelling and sanctions (Benson, 1984; Box, 1983) by being too big to fail and, consequently, too big to jail (Garrett, 2014), not qualifying as typical folk devils (Levi, 2009) and having the power to counter and engage in a blame-game (Huisman, 2011; Levi, 2009).

Most existing studies that touch upon the wider framework of reactions to corporate deviance can be distinguished in more traditional, top-down approaches of formal labelling by official authorities and alternative approaches of informal labelling in the form of third-party control (Gunningham, Phillipson \& Grabosky, 1999) or public disapproval (Elffers et al., 2019; Van Erp, 2016). Still, literature on labelling corporations, or more generally white-collar offenders, is limited (Huisman, 2011). Nonetheless, there have been some efforts made to bridge this gap (see Benson, 1984; Brants \& Brants, 1991; Huisman, 2011). In line with Becker (1963), Brants \& Brants (1991) stress that the social construction of any type of behaviour as deviant is always the result of an interplay between formal and informal labelling. Their book offers an intriguing analysis of the criminalisation of fraud in the 1980s in the Netherlands as a result of public and political outcries following several corporate scandals (Brants \& Brants, 1991). Huisman's (2011) article on the labelling of bankers after the financial crisis, as one of the few studies directly linking both approaches, concludes that the labelling approach is of limited applicability for white-collar crime. While, on the one hand, the article shows first attempts to label bankers, on the other hand, it shows counter-reactions or public apologies and the promise for improvements by the banks, preventing these labels from sticking (Huisman, 2011). Still, Huisman concludes that the labelling approach offers an interesting perspective on the social construction of corporate harms, such as the financial crisis.

In line with this, the present article argues that criminologists still could (or rather should) apply the labelling approach to the corporate context. Firstly, the labelling framework helps criminologists to move beyond legal definitions and the lack of (formal) sanctions of corporate deviance by authorities. Secondly, by examining corporate norm-violations as a process of judgment, the labelling approach offers insights in the question how we get to some agreed-upon rule for 
corporate deviance from a micro, meso and macro level perspective of reactions. Even more, it provides ground for further insights in the questions under which conditions corporate deviancy is (and is not) labelled and why, which characteristics account for that (non-)labelling of corporate activities and lastly, who labels corporations. Thereby, it can help to understand differences in the construction of corporate deviance in which corporations that slightly transgress the rules might be labelled, some sector such as the financial one, are extensively scapegoated, while others who objectively commit more severe violations might not be labelled.

Regardless of the added value for the understanding of corporate deviance, the transition to late-modernity, in which the labelling approach nowadays operates, changes several factors in the process of labelling. The highly interactive, autonomous, easily accessible and multidirectional communication via social media (Aas, 2013; Bauman, 2012; Friedrichs, 2007; Whelan et al., 2013) challenges the traditional labelling approach. At the same time, state sovereignty, and subsequently a traditional top-down approach of labelling, is largely challenged by the dominance of multi-national corporations. I will refer to challenges, not because all the developments are challenging by nature, some of them are rather new opportunities, but because they explicitly challenge the traditional approach of labelling. Firstly, the understanding of power structures needs to be re-examined. And secondly, these challenges have led to three major changes in the process of labelling, regarding 1) who labels, 2) how people label and 3) who is labelled. In order to address these changes properly, a revisited labelling approach is introduced.

\section{Beyond sovereign power}

The concept of power is crucial in most scholars' understanding of the (traditional) process of labelling (e.g. Huisman, 2011; Schur, 1971). Both imposing one's rules on others and the ability to avoid labelling requires economic, political or social power (Becker, 1963; Schur, 1971). In the process of labelling (see Figure 1), power thus interferes with steps 2 a-e, namely the characteristics determining the societal reaction, and consequently whether an act is labelled and whether this label becomes a master status (steps 3 and 4). The traditional process of labelling therefore works best in situations of power gaps (Becker, 1963; Huisman, 2011). Based on the top-down perspective of labelling, labelling is often afflicted to state-power; states in their sovereign role have the power to sanction. This singular sovereignty, however, does neither do justice to the labelling approach nor the economic, political and societal landscape of the late-modern society.

Even more, the classical top-down approach loses explanatory power for corporate deviances. Labelling corporations might never be enforced top-down, given corporations' power. In late-modernity, where corporations are the dominant power source, they have in many ways acquired a status of corporate sovereignty (Snyder, 2004), being similar to the sovereignty of the state. Corporations are increasingly taking on (or over) roles initially held by the state and exercise politi- 
cal influence. Facebook's announcement to enter the financial market by introducing their own cryptocurrency Libra is just one current example of this development. In The Power Elite (1956) by C. Wright Mills, power is distributed among military, politics and corporations. The Power Elite refers to people in positions to realize their will regardless of others' resistance, being in the position to make decisions with major consequences for others who lack that power. The labelling of behaviour as deviant is part of this. In times where "governments are increasingly the puppets of corporations and financial special interests" (Friedrichs, 2007: 168), the power relations have ultimately shifted to the benefit of (multinational) corporations (Aas, 2013; Friedrichs, 2007). While the state remains the final actor in control by limiting corporate actions through regulation and being able to enforce rules on others, the lines between politics and business are increasingly blurry (Aas, 2013; Friedrichs, 2009; Snyder, 2004). Political decisions are often subordinate to and dependent on the economic interest (Friedrichs, 2009). This subordinate position once more became evident in the recent proposition on the abolition of the dividend tax in the Netherlands; a proposition mainly guided by the interest of large corporations such as Shell and Unilever (Bollen, 2018). In a debate on whether to relocate its Headquarter from London to Rotterdam, the British-Dutch company tied its decision to the premise of abolishing the dividend tax. After continuous rebellion by British shareholders (with ten shareholders together owning a 12 percent stake of Unilever) publicly speaking out against the plan to relocate, Unilever eventually had to abandon its plan; the headquarter remains in London and the Dutch government refrained from the tax abolition. The current government has been increasingly portrayed as the "cabinet of the multinationals" by media and opposition parties (see NRC, 11 September 2019, de Volkskrant, 16 December 2017, De Telegraaf, 10 October 2017). Likewise, people's lives nowadays are increasingly shaped by corporate actors (especially the Big Five) in the making of identity, giving meaning and use of their services as a platform for expression (control function); roles traditionally inherited by the state (Snyder, 2004).

While on the one hand, corporations dominate the economic, political and social landscape, on the other hand, the open, late-modern society no longer has one clear centre of power (Van Erp, 2016). Instead of being a possessive feature, power is enacted (Foucault, 1977) in the process of giving, identifying and interpreting meaning by different actors. The basic premises of the labelling approach in many ways reflect Foucault's idea of diffuse and relational power structures. Power is relative and enforcing rules "may be everyone's job" (Becker, 1963: 2). The reality of norms and norm-violations is produced through power. People as well as organizations have always found ways to resist the dominant power by challenging existing norms. With information technology, this has become easier for a wider range of people. Online zones, however, are neither free of power issues as, firstly, what can be posted is regulated by the big technology corporations and governments (control function) and secondly, power still determines the impact that possible labelling has. 
Power in late-modernity is thus not inhibited by a singular party, but rather diffused. Likewise, the labelling approach has been often misunderstood on this aspect, claiming that power differentials are a fundamental precondition for the process of labelling; a position this paper contests. While on the one hand, corporations have taken over many functions traditionally inhibited by the state, acquiring a sovereign-like status, on the other hand people have been empowered through the rise of information technology. By examining corporate deviance from a labelling perspective, we can gain deeper insights in these complex relations and diffused power games.

\section{Who labels: New moral entrepreneurs?}

The first, if not the most significant, change in the process of labelling concerns the central actor of labelling; in other words, who labels. Becker coined people who take the initiative of making rules moral entrepreneurs (Becker, 1963: 157). Moral entrepreneurs are the ones who construct deviancy. They are responsible for promoting the process of labelling (Becker, 1963). Moral entrepreneurs traditionally mostly translate back into authorities as rule creators and rule enforcers, such as police officers. Rule creators often follow moral crusades or 'holy missions' (Becker, 1963) to impose their own convictions on others. If moral entrepreneurs manage to convince others of their mission and have sufficient power to implement their rules, this typically leads to the criminalisation of certain conduct. Moral enterprises can likewise have the opposite effect; that is the normalization of certain conduct as an outcome of a successful moral crusade (Müller, 2018). The concept of moral entrepreneurs has recently been in the spotlight of an issue of this journal called 'Moral Entrepreneurs in the 21st century' (Tijdschrift voor Cultuur \& Criminaliteit 03/2018). The articles of this issue challenge the idea of moral enterprises by pinpointing the central role of the neo-liberal agenda in the making and enforcement of rules. Likewise, the articles introduce (new) moral entrepreneurs outside the traditional spectrum in Becker's Outsiders; that is university ethical committees (Faria \& Eski, 2018), doctors (Müller, 2018) and directors of Cannabis Social Clubs (Pardal, 2018).

In line with these, this article argues for a diversification of moral entrepreneurs. In contrast to these articles, this diversification is, however, directly traced back to the transition into late-modernity and especially the rise of the Internet. In times of social media, basically everybody can become a moral entrepreneur on the Internet (empowerment function). As an open and easily accessible platform, social media have resulted in an expansion of actors or moral entrepreneurs who can apply labels outside the authoritative spectrum. The threshold for tweeting, sharing or commenting online is comparably low, enabling all kinds of people to directly and actively participate in the construction of corporate deviance. Therefore, as a first step towards a revisited labelling approach, an inclusion of more diverse moral entrepreneurs beyond the authoritative spectrum (read: formal labelling) is proposed; an adaptation that actually reflects Becker's Outsiders (e.g. dance musicians labelling their audience as 'squares'; a term used by musicians to refer to outsiders who lack the artistic gift (Becker, 1963: 85). Moral entrepre- 
neurs in the end are those who claim something to be of social concern and draw attention to this act. Similar to the transformations of naming and shaming practices due to social media and the increasing threat of reputational damage originating from social media campaigns by NGOs and the public (Van Erp, 2016), the dynamics of the approach of labelling shift in times of trial by media. Although not being the ones in charge of making decisions, all kinds of people, regardless of their position of power, can substantially influence debates (Van Erp, 2016) and change the discourse on what is regarded as normal or deviant behaviour. Given the diversification of moral entrepreneurs, labelling can take two more, so far rather neglected, forms; that is horizontal or bottom-up labelling. The type of moral entrepreneurs then defines the type of labelling.

Horizontal labelling refers to the labelling by peer groups who share either similar interests, background or social status. Therefore, one can also speak of peer labelling. In the context of corporate deviance, a focus on job-related peers entailing employees, business partners, investors, competitors or other economic stakeholders, is particularly interesting. They are likely to matter and influence each other's thinking, behaviour, beliefs and ultimately a corporation's reputation (Braithwaite, 1989). In other words, they are an important source for approval and comparison. Empirical evidence for horizontal labelling is scarce. That, however, does not necessarily mean that horizontal labelling does not take place. Rather, such reactions are unlikely to be disclosed to the broader public (see Meerts, 2018; Van de Bunt, 2010) and/or existent, 'creative' labels might not be identified as such and thus not linked to deviance. There are however some examples or first attempts of peer-labelling that serve as an indicator for the relevance of incorporating the horizontal perspective into the labelling approach. The practice of whistle-blowing is an example hereof. Whistle-blowing, leaking internal misconduct or wrongdoing to raise public or governmental awareness, by definition illustrates the horizontal peer perspective from within an industry, corporation or other institutional setting. Horizontal labelling and whistle-blowing in many ways, are similar to each other as both focus on the creation of a certain behaviour as a deviant one; in other words, the labelling of certain behaviour. Looking at whistle-blowing from a labelling perspective is interesting for its focus on which (and consequently why) behaviour gets defined as deviant by its peers. Examples of whistle-blowing in the corporate context are the leaking of the security fraud at JP Morgan Chase by the former security attorney Alayne Fleischmann or the disclosure of the accounting fraud at Enron by one of the world's most famous whistle-blowers, Sherron Watkins. In these cases, unlike in the traditional process of labelling, mostly the person taking the initiative to label is othered by the corporation or industry; breaking the 'walls of secrecy' is often sanctioned with dismissal (Van de Bunt, 2010). Similarly, there have been efforts by larger companies to advocate for high certification procedures and standards that are difficult to comply with for small businesses due to their competitive disadvantage. Small businesses are then labelled by the big ones to push (or rather keep) them out of the market (Eshuis, 1997). Other examples include Shell's labelling of AFPM and thereby indirectly labelling corporations that are still affili- 
ated with the organization or Greenpeace, as a global organization with about 3,000 staff members, thousands of volunteers and activists and a turnover of 83,940 000 euros (Greenpeace, 2016) labelling several multi-nationals (e.g. Shell, Volkswagen, Nestlé) for environmental harms. Following the ING money laundering scandal, the reactions by other Dutch banks likewise indicate that incorporating the peer reactions offers interesting insights. ING bank, the largest bank of the Netherlands, in September 2018 made headlines with the announcement of a 775 million euro settlement for serious and structural violations of the Money Laundering and Counter-Terrorist Financing (Prevention) Act. The settlement is the largest ever in the Netherlands. While responses by other banks are foremost of an understanding nature, they have likewise announced to tighten their Know Your Customer and Customer Due Diligence programs (ABN AMRO \& Rabobank) and terminate contracts with high risk segments for money-laundering such as soccer clubs (Rabobank).

Bottom-up labelling refers to the labelling by the broader public and institutions such as non-governmental institutions or trade unions. Social movements, for instance, are (and used to be) an example of this more diverse groups of moral entrepreneurs. Their core business is to raise awareness of a social problem and persuade people that a change (for instance a policy reform) is needed; a definition very much equalling the concept of the 'crusading reformer' (Becker, 1963: 147f). An expansion to bottom-up labelling is supported by recent (populist) movements against the powerful in the neo-liberal system. It mainly targets crimes by the powerful, which are usually not on the radar of traditional labelling. The contemplation of norms and values counteracting the 'profit tunnel vision' and constant anomie of power illusions in the neo-liberal, globalised system (Van Stokkom, 2018) is thus a specific characteristic of bottom-up labelling (of corporate deviance). The 'common people' have in that sense filled the vacuum which the disappearance of a moral compass among (social) institutions has created (Van Stokkom, 2018). This third-party control by non-commercial actors (Gunningham et al., 1999) has been the focus of the study Publiek als Scherprechter by Elffers et al. (2019). In their study, they address the question whether social disapproval can and should be created through the public disclosure of norm-violations by authorities. Their research demonstrates the inherent risk of reputational damage, loss of control and the risk of backfiring as public reactions take their own spin and plausibly revile authorities (Elffers et al., 2019). The ING money-laundering case, amongst other things, illustrates this backfiring as criticism was not only geared towards the bank, but also directly targeted the Netherlands Public Prosecution Service and regulatory authorities. Much bottom-up labelling of corporations can be linked back to the 'Occupy Movement', specifically targeting the omnipresent power of large (financial) corporations and their control over the political and economic system. While the general success of Occupy is debated, it successfully labelled financial institutions and did raise awareness for the powerful $1 \%$ of society. The notion of 'the $1 \%$ ' has become a prominent label among politicians and society to discredit the financial elite that continues to live on beyond the movement itself; in other words: the label stuck. 
In contrast to horizontal labelling, examples of bottom-up labelling are numerous: the 'Occupy Movement', the 'Yellow Vest Movement' in France or the climate lawsuit against Shell filed by the Dutch environmental organisation Milieudefensie, six other NGOs and 17,379 co-plaintiffs in the Netherlands, depicting Shell as the "largest polluter in the Netherlands" that is "putting our future at risk" (Milieudefensie, 2019). Likewise, Facebook (data privacy), Starbucks (tax avoidance), Nike (labour exploitation) and Volkswagen (Dieselgate) have been publicly labelled for their misconducts.

\section{How people label: Online labelling}

With its fast, cheap and highly interactive means of communication, digital globalization has created a new platform for all people who have access to it (Friedrichs, 2007; Whelan et al., 2013). Technology has thus also changed the ways in which and canals through which people frame behaviour. While printed newspaper and television were the predominant media sources in Becker's Outsiders, the process of labelling now faces new, more interactive means of communication. People constantly message, tweet, post, comment, react, share or like. Labelling has thus entered the online sphere and can no longer only be understood in the context of offline interactions. The process of labelling has thus, for a large part, shifted to an interactive, digital creation of deviancy. It can be born, diffused and maintained in the digital space. Information technology influences the ways in which information and the societal reactions they evoke, are accessed, spread and perceived. The giving of meaning, social reality and thus social problems and deviance has a long tradition in the media discourse. Media can act as a platform, as a signifier, as an operator and as claim makers (Bouabid, 2018). People's reactions to events are therefore based on media information. Likewise, most reactions on social media are based on newspaper or television reports which are subsequently shared online. One post on Twitter can quickly result in a flood of discussions and comments. What is regarded as deviance is thus highly shaped by the online world. On social media, people can directly construct, process and interpret information, all processes usually inhibited by the (old) media. Even formal labelling by authorities is linked to online features, for instance through the disclosure of norm-violations on authority's homepages or placement on social media accounts. While for vertical forms of labelling, it is often deliberately chosen to use the Internet as a tool in the process of labelling corporations, horizontal labelling by peers is unlikely to take place openly online.

Labelling someone deviant online, regardless of whether it concerns a person or a whole institution, just like offline labelling, can have detrimental consequences. In contrast to offline labelling, however, online labelling is more persistent and openly accessible to a variety of people across the globe. Any type of norm-violation, scandal or allegations against corporations can, once it has a digital footprint, easily be re-found at any time and any place (see Lageson \& Maruna, 2018). Technology thus contributes to the exposure of those who are labelled and those who label, changing the dynamic between the two (Lageson \& Maruna, 2018: 114). Likewise, the fragmentation and self-selectivity of social media networks 
enables people to create and select their own news environment, choose whom and what to follow and easily block out other, divergent voices. While this creates a risk of misinformation and tunnel vision, the online sphere also allows for techniques to avoid labelling. While being increasingly scrutinized online, corporations also increasingly control the digital space and can use the Internet for efforts of un-labelling or greenwashing. Most corporations are nowadays rather active online, having their own Twitter or Facebook accounts, which are followed by thousands of people. They thus themselves actively participate in the sharing and maintenance of information.

\section{Who is labelled: Labelling institutions}

In 2014, the non-governmental organization Greenpeace started a campaign against multiple corporations to 'Save the Arctic'. In their global campaign Greenpeace called on the Danish toymaker Lego to stop its co-promotion with oil-giant Shell, after Shell has released its plans to drill in the Arctic (Polisano, 2014). The campaign was promoted by the release of the viral video. ${ }^{1}$ Everything is NOT awesome', depicting a Lego-built Arctic which is slowly covered in oil. The video explicitly aimed at targeting Lego's core value of inspiring children by demonstrating the discrepancy between Lego's core values and its actions; that is the business relation with Shell. Shell, then, was labelled as "the polluter of our kids' imagination" (Polisano, 2014). Social media empowered Greenpeace and its leverage power by the initiation of several social movements involving children campaigning for the termination of Lego's cooperation with Shell. After a couple of weeks of enduring resistance on Lego's side, the toymaker eventually declared that it will not renew its deal on selling Shell-branded Lego sets at petrol stations. Horizontal labelling did thus not occur in the first place, but only later emerged with increasing bottom-up labelling by a wide group, including their primary target group, that is kids and their parents.

The campaign is an example of how business-related peers and social movements can influence corporate decision making. At the same time, the reactions by Greenpeace and Lego do not fit the traditional labelling approach. Rather, this example demonstrates the need for a revisited labelling approach due to the broadening of moral entrepreneurs or stakeholders, the role of social media as a platform to construct, process and interpret deviant behaviour and, lastly, the targeting of institutions or more precisely corporations. As a third change in the process of labelling, we thus see a diversification of who is labelled. Efforts of labelling have moved beyond its traditional reach of specifically othering individuals or groups and classes of people like for instance 'the youth gangs', 'junkies' or the 'underclass' (Becker, 1963). While the traditional labelling approach has been applied to groups and classes, it is not applied to institutions (political, religious, financial, etc.); rather, it flows from these institutions to the lower classes or individuals. Institutions thus are mainly dealt with as subjects who assign labels; not as objects at the receiving end (Becker, 1963). With an extension towards hori- 
zontal and bottom-up labelling, the process is no longer restricted to individuals, groups or classes. Rather, it specifically targets political and economic institutions. Labelling corporations thus goes beyond singling out a scapegoat or rotten apple in an organization. Rather this labelling focuses on the meso-level, viewing the corporation as an acting entity, with its own culture, practices, guidelines and responsibilities. Labels, in contrast to the traditional labelling approach, then often focus on the economic aspects of the behaviour. While labelled individuals or classes are othered and socially excluded, the labelling of corporations rather targets their credibility, reputation or social responsibility.

Another illustration of the labelling of corporations is the ING money laundering case. This case demonstrates both efforts of formal labelling, peer labelling, bottom-up labelling, but also absence of labelling and un-labelling. The norm-violations were officially labelled as 'corporate crime' by the Public Prosecution Service (NPPS, 2018: 21). The case dominated the (national) media landscape for days; mostly sparking (moral) criticism on the corporate culture, the settlement and the lack of personal consequences (Chin-A-Fo \& Driessen, 2018; Piersma, 2018). Twitter posts by Dutch news media such as NOS, Zembla or De Telegraaf have resulted in a flood of re-tweets, hashtags such as \#classjustice, \#whitecollarcriminals, \#shameING, banker bashing and users depicting the bank as 'corrupt', 'fraudsters' or a 'criminal organization'. Financial analysts quarterly covering ING, ${ }^{2}$ on the contrary, were mostly concerned about the financial consequences of the settlement and costs of compliance staff (ING, 2018), thus avoiding any moral judgement or labelling of the bank. The case, however, also demonstrates more successful efforts of peer labelling. At the 2019 Annual General Meeting, multiple shareholders expressed their anger and lost trust in the bank. ING was labelled a 'money laundering machine's by one shareholder. The Dutch association for investors VEB (Vereniging van Effectenbezitters), in a letter directed at ING only two days after the publication of the settlement, expressed their "bewilderment and great concern" about the practices, accusing ING of "deliberately transgressing existing laws and regulations” by prioritizing profit (VEB, 2018). And lastly, the ING engaged in processes of un-labelling. The bank continuously stressed the launch of its global Know Your Customer (KYC) Enhancement Programme, said to take full responsibly and necessary (personal and operational) measures and initiated several (expert) meetings with shareholders (ING Investor Day, 25 March 2019) or other parties (such as Financiële Poort - De bank als poortwachter, 19 June 2019).

2 For a complete list of the analyst coverage see www.ing.com/Investor-relations/Analystcoverage.htm.

3 These insights are derived from the attendance of the ING 2019 Annual Shareholder Meeting on 23 April 2019 in Amsterdam. The meeting can be openly viewed at https://webcast.ing.com/ ingagm2019/. 


\section{Conclusion \& discussion}

In Outsiders, Becker (1963: 163) explicitly criticized that most research on deviance is mainly concerned with the "people who break the rules rather than with those who make and enforce them". As an answer to this critique, this article has shed light on the process of labelling in cases where those who break the rules are the very ones who are involved in the creation and maintenance of them; namely (multi-national) corporations. The labelling of corporations has so far rather been neglected in research. Most literature suggests that labelling is mainly executed top-down and that corporations continuously manage to evade labelling processes. Corporations are not considered as objects towards whom labelling is targeted, but rather as actors who hamper such processes and who, as moral entrepreneurs, influence which behaviour is labelled deviant. In this article, I examined to what extent the labelling approach can and should be applied to corporate deviance and how the process of labelling has changed in late-modernity. Based on theoretical analysis and recent examples of labelling corporate behaviour as deviant, this article suggests that the labelling perspective offers interesting insights in the phenomenon of corporate deviance. It enables criminologists to identify characteristics or factors that contribute to (not) defining certain corporate activities or norm violations as deviant. Which corporations and corporate activities get defined as criminal or deviant? And why? Who defines which corporate activities are deviant? How do definitions of corporate deviance change over time? The labelling perspective offers an opportunity for criminologists to keep questioning what is taken for granted and to find answers to these questions by uncovering the underlying processes. At the same time, it provides insights in how businesses themselves create 'outsiders' and how corporations impose their standards on society by defining what is deviant. The labelling perspective also offers an interesting angle on the management of reputation, by exploring processes of un-labelling.

In light of a transformation into late-modernity, the process of labelling has substantially changed, resulting in a revisited labelling approach specifically encompassing corporate deviances and social media as a new platform for labelling. The Internet and especially social media set a unique context for the process of labelling. The revisited labelling approach differs from the traditional approach in three aspects. Firstly, the group of moral entrepreneurs is broader, including the public or non-governmental organizations (bottom-up labelling) and peers (horizontal labelling). Secondly, labelling to a large degree is initiated, performed and communicated online through social media. The construction of deviance in latemodernity is thus highly dependent on digital globalization. This however does not imply that offline labelling has lost its relevance; rather any approach to labelling should incorporate both forms. And thirdly, the revisited labelling approach specifically targets institutions. In late-modernity, corporations have become the dominant power elite. They have acquired a sovereign status in many ways similar to the one of states and likewise control the political, economic, social and digital space. Online labelling is thus highly controlled by the big tech companies. 
This is particularly evident in the case of Facebook. Facebook is often used by people as a platform to initiate, spread and maintain information. Consequently, it serves as a platform for the construction of corporate deviance too. At the same time, Facebook itself has been criticised in light of its data protection scandal. Despite several (congressional) hearings and a trend among (young) people (among the supporters are celebrities such as Will Ferrell, Cher and Jim Carrey and businessmen, such as Elon Musk and Brian Acton, the co-founder of WhatsApp) to delete Facebook in response to the scandal, Facebook hardly faced any labelling. With increasing sovereignty and control, corporations also face demands for more responsibility. Failing to meet these demands can then result in labelling. The revisited approach thus differs from the traditional approach with regard to the role of power and the shift in moral entrepreneurs.

Labelling corporations remains challenging. For corporate labelling to be successful, it needs to gain a momentum of either many voices (bottom-up labelling) or particularly influential voices (horizontal labelling). Corporate behaviour and corporate structures, including norm-violations, are often non-transparent to outsiders, violations are dealt with internally rather than being disclosed (Meerts, 2018) and behaviour is normalized and neutralized in the corporate setting (Van Rooij \& Fine, 2018). Moreover, corporations can and do counter-react to labelling (Huisman, 2011). In the ING money laundering case, we have seen multiple efforts of un-labelling by the bank. Given corporations' power to manage the process and consequences of labelling, the question arises what the value of labelling corporations is if these labels do not stick (see Huisman, 2011; Moerings \& Van de Bunt, 1976)? While labels traditionally become a master status, this hardly ever happens in the corporate context. Even corporations that have been publicly labelled are not identified as deviant first. In other words, what impact or consequences does being labelled have on corporations? Labelling is traditionally accompanied by social exclusion. For corporations, social exclusion is rather translated in reputational damage as one of the greatest threats (Van Erp, 2007; Van Wingerde, 2012). Horizontal and bottom-up labelling can cause such reputational damage; in the form of loss of trust, loss of costumers or boycotts on certain services of products (bottom-up labelling) (Elffers et al., 2019) or loss of trust, loss of contracting partners or suppliers or a weakened position within the industry (horizontal labelling). Corporate sanctions are, however, often published anonymously in the economic interest to avoid the risk of reputational damage. In cases where primary deviancy remains undetected or anonymous, labelling fails to appear. And then still, we need to recognise that in many cases of corporate deviancy, we still do not see any or hardly any labelling (think for instance of the bribery scandals at Samsung). Likewise, no cases of peer labelling of Volkswagen by the automobile industry and suppliers are known. The practice of tax avoidance (minimizing taxes within the given legal framework) by corporations has recently received much attention. Particularly Starbucks has been extensively shamed. Starbucks is however only one name on a long list of corporations continuously and effectively avoiding taxes. Why is Starbucks labelled, while tax avoidance by other corporations (e.g. Amazon, Google, IBM, Uber, Microsoft, 
Unilever or Philips) seems to be regarded less harmful or at least, does not get labelled the same way? For the big tech corporations, their monopoly-like existence and incorporations of services in people's everyday lives, that both labelling and real consequences of such labelling are less likely. This is supported by a study conducted by Van Baar, Enneking, Van Erp \& Engelen (forthcoming ${ }^{4}$ ), who found that the impact of media accusations following corporate norm-violations on corporate stock prices is marginal. Reputational damage does thus not necessarily follow. The labelling perspective can help criminologists to gain insights in these differences in the construction of what constitutes as corporate deviance.

With growing public outrage and disapproval of the neo-liberal, profit-oriented agenda and of corporations maliciously hazarding the consequences of their norm-violations, the rules of the game have possibly changed in recent times. The current developments of ING being formally labelled and Shell facing several court cases could be the beginning of a transition; a transition to which the labelling approach can make important contributions. Social media as the new mass media is likely to become even more important for the process of labelling than it already is now. One of the major challenges for criminologists now lies in "examining how people and social institutions adjust to these developments locally, through culturally specific strategies" (Aas, 2013: 6). The revisited labelling approach, by directly targeting one of the most undebated characteristics of the labelling approach; that is its top-down focus and, rather, introducing a labelling approach that can take vertical - both top-down and bottom-up - and horizontal forms, offers a fruitful framework for this examination.

\section{Bibliography}

Aas, K. F. (2013). Globalization and crime . SAGE Publications Limited.

Bauman, Z. (2012), Liquid Modernity. 2nd Edition. Cambridge: Polity Press.

Becker, H. S. (1973). Outsiders. Studies in the sociology of deviance. (enlarged ed.).

Becker, H. S. (1963). Outsiders. Studies in the sociology of deviance.

Benson, M. L. (1984). 'The fall from grace: Loss of occupational status as a consequence of conviction for a white collar crime'. Criminology, 22(4), 573-593.

Beunderman, M. (2019). Big Tech is machtig, maar er is wat aan te doen. NRC, 15.07.2019. Retrieved from www.nrc.nl/nieuws/2019/07/15/big-tech-is-machtig-maar-er-is-wataan-te-doen-a3967170.

Blumer, H. (1969). Symbolic interactionism: Perspective and method. Univ of California Press.

Bollen, T. (2018). 'Door Shell gefinancierd onderzoek stond aan de basis van afschaffing dividendbelasting'. Follow The Money, 07.06.2018. Retrieved from www.ftm.nl/ artikelen/shell-rsm-onderzoek-dividendbelasting?share $=1$.

Bouabid, A. (2018). De Marokkanenpaniek; een geïntegreerde morele paniekbenadering van het stigma 'Marokkaan' in Nederland.

4 Information derived from: www.uu.nl/agenda/expert-meeting-corporate-human-rightsviolations-and-reputational-damage. 
Bousso, R. (2019). 'Citing climate differences, Shell walks away from U.S. refining lobby'. Reuters, 02.04.2019. Retrieved from www.reuters.com/article/us-shell-afpmidUSKCN1RE0VB.

Box, S. (1983). Power, Crime, and Mystification. London: Tavistock.

Braithwaite, J. (1989). Crime, shame and reintegration. Cambridge University Press.

Brants, C. H., \& Brants, K. L. K. (1991). De sociale constructie van fraude. Gouda Quint.

Castells, M. (2015). Networks of outrage and hope: Social movements in the Internet age. John Wiley \& Sons.

Chin-A-Fo, H. \& Driessen, C. (2018). 'Schikking ING is beter dan proces'. NRC Handelsblad, 04.09.2018. Retrieved from www.nrc.nl/nieuws/2018/09/04/schikking-ing-is-beterdan-proces-a1615296.

Cohen, S. (1972). Folk devils and moral panics. The creation of the Mods and Rockers. London: Routledge.

Davis, M. (2008). 'Bauman on Globalization-The Human Consequences of a Liquid World'. The Sociology of Zygmunt Bauman Challenges and Critique, 137-153.

Elffers, H., van Bemmelen, R., Hesseling, E. \& Ramaker, S. (2019). Publiek als scherprechter: Kan aansturen op publieke verontwaardiging regelnavolging bevorderen? Den Haag: Boom criminologie.

Eshuis, R. J. J., Graaf, P. D., Kouwenberg, R. F., \& van Wetten, J. W. (1997). Ondernemend milieubeleid. WODC.

Faria, R., \& Eski, Y. (2018). 'Een wolf onder de wolven. Ethiek en Ethische Commissies in criminologisch onderzoek naar "the powerful". Tijdschrift over Cultuur en Criminaliteit, 8(3), 43.

Foucault, M. (1977). Discipline and Punish: The Birth of the Prison, New York: Random House.

Friedrichs, D. O. (2007). 'White-collar crime in a postmodern, globalized world', in: International handbook of white-collar and corporate crime (pp. 163-184). Springer, Boston, MA.

Friedrichs, D. O. (2009). Trusted criminals: White collar crime in contemporary society. Cengage Learning.

Garfinkel, H. (1956). 'Conditions of successful degradation ceremonies'. American Journal of Sociology, 61(5), 420-424.

Garrett, B. (2014). Too big to jail: How prosecutors compromise with corporations. Harvard University Press.

Goffman, E. (1963). Stigma: Notes on the Management of Spoiled Identity. Englewood Cliffs, NJ: Prentice Hall

Huisman, W. (2011). 'Etiketten plakken op bankiers: labelling van witteboordencriminaliteit na de kredietcrisis', in: J.P. van der Leun, E.R. Muller, N. van der Schee, P.M. Schuyt \& M.A.H. van der Woude (red.), De vogel vrij. Liber amoricum Martin Moerings. Den Haag: Boom Juridische uitgevers.

Hüzeir, V. (2019). Erasmus University silently broke with Shell. NRC, 13.03.2019. Retrieved from www.nrc.nl/nieuws/2019/03/13/in-stilte-brak-de-erasmus-univer siteit-met-shell-a3952618.

Lageson, S. E., \& Maruna, S. (2018). 'Digital degradation: Stigma management in the internet age'. Punishment \& Society, 20(1), 113-133.

Lemert, E. M. (1972). Human deviance, social problems, and social control. Englewood Cliffs, NJ, Prentice-Hall.

Levi, M. (2009). 'Suite revenge? The shaping of folk devils and moral panics about whitecollar crimes'. The British Journal of Criminology, 49(1), 48-67. 
Matsueda, R. L. (1992). 'Reflected appraisals, parental labeling, and delinquency: Specifying a symbolic interactionist theory'. American Journal of Sociology, 97(6), 1577-1611.

Mead, G. H. (1934). Mind, Self, and Society from the Standpoint of a Social Behaviorist. Chicago: University of Chicago Press

Meerts, C. A. (2018). The Semi-Autonomous World of Corporate Investigators: Modus vivendi, legality and control (Doctoral dissertation, Criminology).

Milieudefensie. (2019). De Klimaatzaak Shell. Een Rechtszaak tegen Shell vanwege onrechtmatig klimaatbeleid. Retrieved from file:///C:/Users/Anna/Downloads/uitgebreide \%20samenvatting\%20dagvaarding,\%20Milieudefensie\%20c.s.\%20vs\%20Shell.pdf.

Moerings, M. (2017). 'Etiketten blijven plakken?', in: Staring R., Swaaningen R. van \& Wingerde K. van (Eds.) Over de muren van stilzwijgen. Liber Amicorum Henk van de Bunt. Den Haag: Boom Criminologie. 191-202.

Moerings, M. \& Van de Bunt, H. (1976). 'Etiketten plakken', in: C. Kelk, M. Moerings, N. Jörg \& P. Moedikdo (Eds.), Recht, macht en manipulatie, Utrecht/Antwerpen: Het Spectrum, p. 155-188.

Müller, T. (2018). 'Artsen en moreel ondernemerschap. De casus van de normalisering van verslavende opioïde pijnstillers in de Verenigde Staten'. Tijdschrift over Cultuur \& Criminaliteit, 8(3), 25-42.

Nelen, H. \& van Gemert, F. (2018). 'De mooie held geveld'. Tijdschrift over Cultuur \& Criminaliteit, (8)2, 3-14.

NPPS. (2019). 'Moerdijk door oog van de naald bij explosie fabriek Shell'. Retrieved 12 July 2019 from www.om.nl/vaste-onderdelen/zoeken/@105826/moerdijk-oog-naald/.

NPPS. (2018). Investigation Houston. Criminal investigation into ING Bank N.V. Statement of Facts and Conclusions of the Netherlands Public Prosecution Service. Retrieved 5 September 2018 from www.om.nl/vaste-onderdelen/zoeken/@103952/ing-pays-775million/.

Pardal, M. (2018). 'Een inkijk in het leiderschap van Cannabis Social Clubs in België: criminelen, activisten, modelburgers?' Tijdschrift over Cultuur en Criminaliteit, 8(3), 7-24.

Passas, N. (2005). 'Lawful but awful: "Legal corporate crimes"'. The journal of socio-economics, 34(6), 771-786.

Piersma, J. (2018). 'OM schuift steeds meer op naar Amerikaanse schikkingspraktijk'. Het Financieele Dagblad, 04.9.2018. Retrieved from https://fd.nl/ondernemen/1268143/ om-schuift-steeds-meer-op-naar-amerikaanse-schikkingspraktijk.

Polisano, E. (2014). 'Greenpeace: how our campaign ended the Lego-Shell partnership'. The Guardian, 10.10.2014. Retrieved from www.theguardian.com/voluntary-sectornetwork/2014/oct/10/greenpeace-lego-shell-climate-change-arctic-oil.

Rengers, M. \& Houtekamer, C. (2019). 'Shell en Damen blokkeren onderzoeken'. NRC, 04.06.2019. Retrieved from www.nrc.nl/nieuws/2019/06/06/shell-damen-blokkerenonderzoeken-a3962956.

Schur, E. M. (1971). Labeling deviant behavior: Its sociological implications (pp. 18-18). New York: Harper \& Row.

Shell. (2018). 'Sustainability report 2018'. Retrieved 1 September 2019 from https:// reports.shell.com/sustainability-report/2018/.

Snyder, F. G. (2004). 'Sharing Sovereignty: Non-State Associations and the Limits of State Power'. Am. UL Rev., 54, 365.

Tannenbaum, F. (1938). Crime and Community. London and New York: Columbia University Press.

Van de Bunt, H. (2010). 'Walls of secrecy and silence: The Madoff case and cartels in the construction industry'. Criminology \& Public Policy, 9(3), 435-453. 
Van der Wagen, W., Althoff, M., \& Van Swaaningen, R. (2016). 'De andere "anderen”: een exploratieve studie naar processen van othering van, door en tussen hackers'. Tijdschrift over Cultuur en Criminaliteit, 6(1), 27-41.

Van Erp, J. (2007). 'Reputational sanctions in private and public regulation'. Erasmus L. Rev., 1, 145.

Van Erp, J. (2016). Toezicht in de open samenleving: Maatschappelijke controle op multinationale ondernemingen. Boom bestuurskunde.

Van Rooij, B., \& Fine, A. (2018). 'Toxic Corporate Culture: Assessing Organizational Processes of Deviancy'. Administrative Sciences, 8(3), 23.

Van Stokkom, B. (2018). 'De anomie van machtsillusies'. Tijdschrift over Cultuur \& Criminaliteit, (8)1, 54-77

Van Wingerde, K. C. (2012). De afschrikking voorbij: Een empirische studie naar afschrikking, generale preventie en regelnaleving in de Nederlandse afvalbranche.

Vaughan, D. (2007). 'Beyond macro-and micro-levels of analysis, organizations, and the cultural fix', in: International handbook of white-collar and corporate crime (pp. 3-24). Springer, Boston, MA.

VEB. (2018). VEB/ING - vragen en aanbevelingen naar aanleiding van bevindingen van het OM, d.d. 4 september 2018. Retrieved from www.veb.net/media/4326/20180906-ingwitwassen-brief.pdf.

Whelan, G., Moon, J., \& Grant, B. (2013). 'Corporations and citizenship arenas in the age of social media'. Journal of Business Ethics, 118(4), 777-790.

Yar, M. (2012). 'E-Crime 2.0: the criminological landscape of new social media'. Information \& Communications Technology Law, 21(3), 207-219. 